\title{
Changes in erythrocyte ATPase activity under different pathological conditions.
}

\author{
Ali A Kherd ${ }^{1}$, Nawal Helmi ${ }^{1,2}$, Khadijah Saeed Balamash ${ }^{1}$, Taha A Kumosani ${ }^{1,2,3}$, \\ Shareefa A AL-Ghamdi ${ }^{1}$, Qari M ${ }^{4}$, Etimad A Huwait ${ }^{1}$, Soonham S Yaghmoor ${ }^{2,3}$, \\ Alaama Nabil ${ }^{5}$, Maryam A AL-Ghamdi ${ }^{1}$, Said S Moselhy ${ }^{1,2,6,7}$
}

1. Biochemistry Department, Faculty of Science, King Abdulaziz University, Jeddah, Kingdom of Saudi Arabia.

2. Experimental Biochemistry Unit, King Fahd Medical Research center KFMRC, Jeddah, Kingdom of Saudi Arabia.

3. Production of natural products for Industrial health Research group, King Abdulaziz University, Jeddah, Kingdom of Saudi Arabia.

4. Hematology department, Faculty of Medical Science, King Abdulaziz University, Jeddah, Kingdom of Saudi Arabia.

5. King Abdulaziz University hospital, Jeddah, Kingdom of Saudi Arabia.

6. Bioactive Natural Products Research Group, King Abdulaziz University, Jeddah, Kingdom of Saudi Arabia.

7. Biochemistry Department, Faculty of science, Ain Shams University, Cairo, Egypt.

\begin{abstract}
Background: Studies have shown that $\mathrm{Na}^{+}-\mathrm{K}^{+}$ATPase activity was altered in disrupted red blood cell membranes and this enzyme is believed to be the site of active transport of $\mathrm{Na}^{+}$and $\mathrm{K}^{+}$in intact red blood cells. The enzyme is often referred to as $\mathrm{Na}^{+}-\mathrm{K}^{+}$pump because it pumps $\mathrm{Na}^{+}$out and $\mathrm{K}^{+}$into the cell against gradients with the concomitant hydrolysis of intracellular ATP.

Objective: The aim of this study was to find out the possibility of using $\mathrm{Na}^{+}-\mathrm{K}^{+}$-ATPase activity as a biomarker for the diagnosis of individuals with different physiological conditions.

Materials and methods: The activity of $\mathrm{Na}^{+}-\mathrm{K}^{+}$ATPase was determined in blood samples collected from different pathological and physiological conditions such as pregnancy, smoking, diabetes and renal dysfunction compared with healthy subjects matched for age and sex.

Results: The $\mathrm{Na}^{+}-\mathrm{K}^{+}$ATPase activity in pregnancy $(0.094 \pm 0.0051 \mu \mathrm{M} \mathrm{Pi} / \mathrm{min} . \mathrm{mg}$ protein), smoking $(0.064 \pm 0.0011 \mu \mathrm{M})$, diabetes $(0.047 \mu \mathrm{M} 0.002 \mu \mathrm{M})$ and kidney disease $(0.069 \pm 0.0014 \mu \mathrm{M})$ was higher compared to the measurements in healthy individuals $(0.0081 \pm 0.0031 \mu \mathrm{M})$.

Conclusion: $\mathrm{Na}^{+}-\mathrm{K}^{+}$ATPase specific activity is a biomarker for the diagnosis of individuals with different physiological diseases. Keywords: $\mathrm{Na}^{+}-\mathrm{K}^{+}$ATPase, red blood cell, pregnancy, smoking, diabetes, kidney diseases.

DOI: https://dx.doi.org/10.4314/ahs.v17i4.31

Cite as: Kherd AA, Helmi N, Balamash KS, Kumosani TA, AL-Ghamdi SA, Qari M, Hunait EA, Yaghmoor SS, Nabil A, AL-Ghamdi MA, Moselhy SS. Changes in erythrocyte ATPase activity under different pathological conditions. Afri Health Sci.2017;17(4):1204-1210. https:/ / dx.doi.org/10.4314/abs.v17i4.31
\end{abstract}

\section{Introduction}

Studies have shown that $\mathrm{Na}^{+}-\mathrm{K}^{+}$-ATPase activity was

\section{Corresponding author:}

Said Salama Moselhy, Department of Biochemistry, Faculty of Science, King Abdulaziz University. Email: moselhy6@hotmail.com altered in disrupted red blood cell membranes ${ }^{1}$ and this enzyme can be the site of active transport of $\mathrm{Na}^{+}$and $\mathrm{K}^{+}$in intact red cells ${ }^{2}$. The enzyme is often referred to as $\mathrm{Na}^{+}-\mathrm{K}^{+}$pump because it pumps $\mathrm{Na}^{+}$out and $\mathrm{K}^{+}$into the cell against gradients with the concomitant hydrolysis of intracellular $\mathrm{ATP}^{3}$. There are three types of ATPase: P-type ATPases, V-type ATPases and ABC transporters for ATP binding cassette. The distinguishing functional characteristic of P-type ATPases is that the hydrolysis of ATP that occurs during the catalytic cycle results in

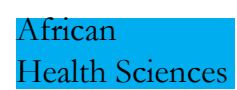

(a) 2017 Kherd et al; licensee African Health Sciences. This is an Open Access article distributed under the termsof the Creative commons Attribution License (https://creativecommons.org/licenses/by/4.0), which permits unrestricted use, distribution, and reproduction in any medium, provided the original work is properly cited. 
the phosphorylation of the transport protein itself. This phosphorylation results in a change in the conformation of the protein that, in turn, plays a part in the translocation of one or more substrate molecules across the membrane ${ }^{4}$.

Erythrocyte $\mathrm{Na}^{+}, \mathrm{K}^{+}$-ATPase, and $\mathrm{Ca}^{-2+}, \mathrm{Mg}^{-2+}$-ATPase activity in young individuals were markedly lower than that in the adults. Intra-erythrocyte free $\mathrm{Ca}^{-2+}$ concentration in young individuals was markedly higher than that in adults ${ }^{3}$. The two ATPases activity in the elderly group over 60 years old were lower than that in young individuals, intra-erythrocytic free $\mathrm{Ca}^{2+}$ concentration in the elderly group was higher than that in young individuals. In all age groups, the three parameters mentioned above in young individuals showed most remarkable change with aging and that changes in young females were more remarkable than that in young males ${ }^{5}$.

Placenta showed an increase of $\mathrm{Na}^{+}, \mathrm{K}^{+}$-ATPase on day 21 of gestation in comparison to day $12^{6}$. Erythrocyte $\mathrm{Na}^{+}, \mathrm{K}^{+}$-ATPase activity was normal in pregnant women, suggesting that the peripheral metabolic status during pregnancy was normal. Increases in both the number and function of the pump may be influenced by factors other than thyroid function ${ }^{7}$.

The red-blood cell membrane possesses an ATP-dependent transport system by which the hydrolysis of one molecule of ATP results in the linked movement of three $\mathrm{Na}^{+}$ions out of the cell and two $\mathrm{K}^{+}$ions into the cell. This active transport process is dependent upon the appropriate concentrations of $\mathrm{Na}^{+}$and $\mathrm{K}^{+}$inside and outside of the cell membrane, and is specifically inhibited by low concentrations of cardiac glycosides ${ }^{8}$.

The $\mathrm{Na}^{+}$transport system represents a complex protein-lipid moiety appropriately orientated within the membrane. The number of $\mathrm{Na}^{+}$and $\mathrm{K}^{+}$transport sites per red cell has been calculated from kinetic data and from the binding of tritium-labeled ouabain to be approximately 200 per cell $^{9-11}$.

The rationale for this study was the possible utility of erythrocyte ATPase as a biomarker of physiological changes in human bodies. This will help in early diagnosis of health status.
The aim of this study was to find out the possibility of using $\mathrm{Na}^{+}-\mathrm{K}^{+}$ATPase specific activity as a biomarker for the diagnosis of individuals with different physiological and pathological conditions.

\section{Subjects and methods}

Sucrose, magnesium chloride hexahydrate, ascorbic acid, sodium chloride, potassium chloride, ammonium molybdate, ethylenediaminetatra-acetic acid (EDTA), sodium hydroxide, sodium dodecyl sulphate (SDS), sulfuric acid , hydrochloric acid and Tris tris [hydroxymethyl] aminoethane were purchased from BDH limited Poole, England. Adenosine-5 - triphosphate disodum salt and ouabain were obtained from Sigma Chemical Company St. Louis, MO, USA.

\section{Subjects}

Human subjects included in this study were selected from four different hospitals in Jeddah area of Saudi Arabia, King Abdulaziz University Hospital, King Fahd Hospital, Al Thaqer Hospital and Maternity Hospital.

Total of 149 subjects were included in this study and divided into two main groups. The first group consisted of 63 normal healthy individuals of the age 23-50 years and this group was used as a control. This control group consisted of 34 males and 27 females. The second group $(n=86)$ consisted of subjects with physiological / conditions which include pregnancy $(n=21)$, smoking $(n=30)$ and pathological conditions such as diabetes $(n=20)$ and kidney disease $(n=15)$. Detailed history, mental, physical status and clinical examination showed that the control group consisted of completely healthy individuals and had not been subject to any therapeutic drugs during the past 4 months of blood sampling. Patients with different physiological changes were confirmed by clinical and biochemical examinations. The subjects were informed of their consent prior to drawing blood samples.

A venous blood sample $5 \mathrm{ml}$ was collected in a heparin's tube from each subject and kept in an icebox. Plasma was separated by centrifugation at $4500 \mathrm{rpm}$ at $4^{\circ} \mathrm{C}$. Precipitated RBC's were washed by isotonic solution $0.9 \% \mathrm{w} / \mathrm{v}$ $\mathrm{NaCl}$, throughout; this step was repeated three times. Another wash with de-ionaized water was performed, and then stored at $-20^{\circ} \mathrm{C}$ overnight. After thawing, the 
supernatant was separated by centrifugation at $8000 \mathrm{rpm}$ for $30 \mathrm{~min}$, and $\mathrm{RBC}$ was used for the $\mathrm{Na}^{+}-\mathrm{K}^{+}$ATPase assay.

\section{Determination of the $\mathrm{Na}^{+}, \mathrm{K}^{+}$-ATPase activity}

The ATPase activity was quantified by measuring the release of Pi from ATP Serrano, 1978. A spectrophotometric method was adopted, the quantity of Pi in the assay was then determined spectrophotometrically against a standard curve derived from solution of known phosphate concentration ${ }^{12}$. One $\mathrm{ml}$ of $\mathrm{RBC}$ homogenate was added to ATPase buffer $50 \mathrm{mM}$ Tris, $3 \mathrm{mM} \mathrm{MgCl}$. 6H2O, $10 \mathrm{mM} \mathrm{KCl}, 0.1 \mathrm{mM}$ EDTA, $100 \mathrm{mM} \mathrm{NaCl}$ at $\mathrm{pH} 7.4$ and +/- Ouabine. Incubated for $5 \mathrm{~min}$ at $37 \mathrm{oC}$ in water bath then $2 \mathrm{mM}$ ATP was added and incubated further for $10 \mathrm{~min}$. Ammonium molybdate solution 2 $\mathrm{ml}$ was added to stop the reaction ${ }^{23}$. By adding $20 \mu \mathrm{l}$ of ascorbic acid, the absorbance of color complex was measured at $750 \mathrm{~nm}^{13}$. The calorimetric method was applied for the measurement of total protein according to the method of Biuret ${ }^{14}$.

\section{Statistical analysis}

The data were logged into personal computer and analyses of data were performed using SPSS statistical package version 22 . T-test was used for comparing means. $\mathrm{P}$ value was considered to be statistically significant if it was $<0.005$.

\section{Results}

In pregnancy, as shown in Figure 1, the mean activity of $\mathrm{Na}^{+}, \mathrm{K}^{+}$-ATPase of healthy females $(\mathrm{n}=21)$ was compared with pregnant women of the same age group. The mean of enzyme activity for pregnant women 0.0094 $\pm 0.001 \mathrm{nmol} \mathrm{Pi} / \mathrm{min}$. mg protein was higher than in healthy women $0.0086 \pm 0.001 \mathrm{nmol} \mathrm{Pi} / \mathrm{min}$. mg protein and there was a highly significant difference between these two groups $(\mathrm{P}=0.007)$.

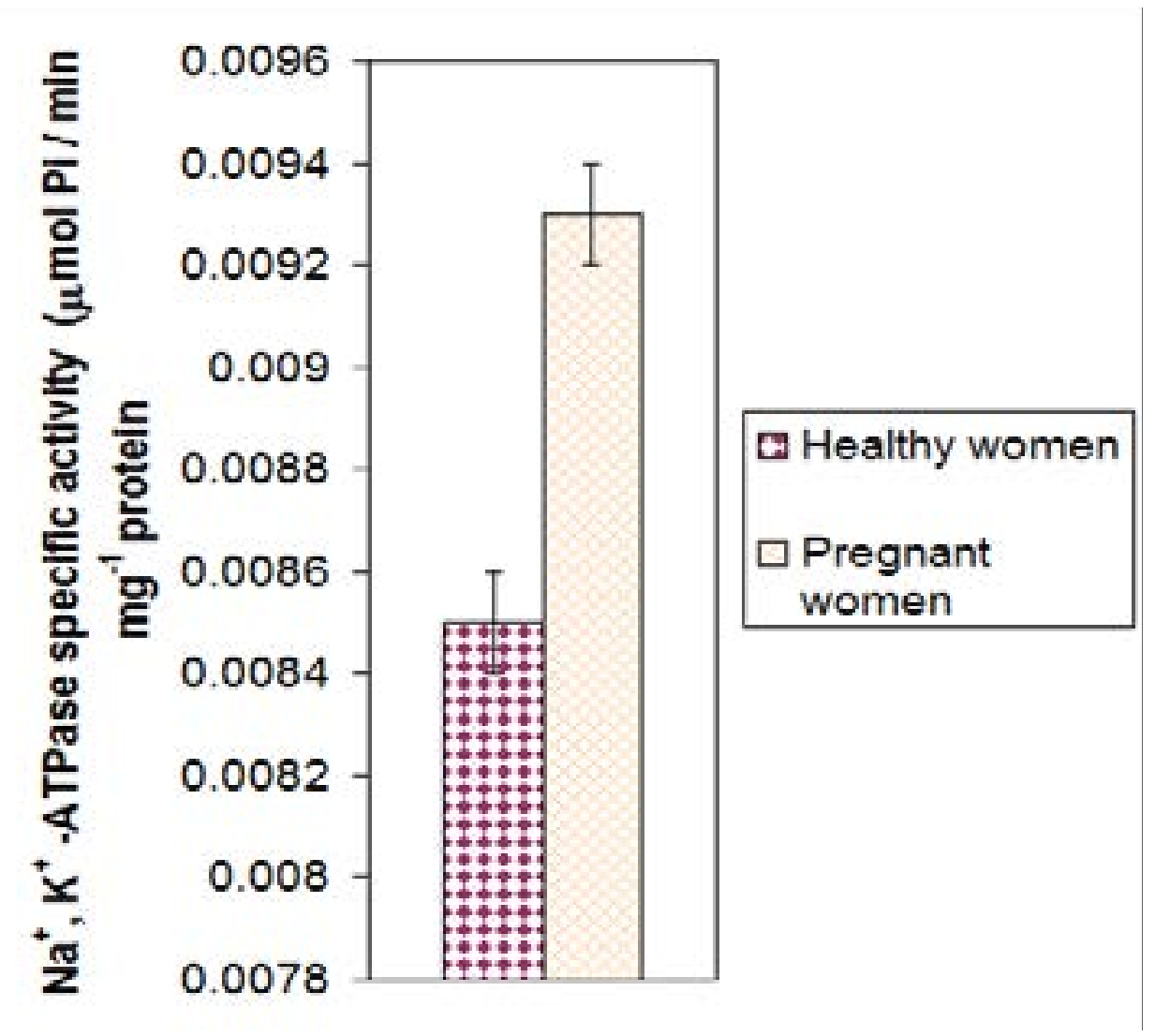

Figure 1:The mean values of $\mathrm{Na}^{+}, \mathrm{K}^{+}$-ATPase specific activity of pregnant females compared to non-pregnant at same age $(\mathrm{p}<0.01)$. 
In smokers, as shown in Figure 2, the activity of $\mathrm{Na}^{+}, \mathrm{K}^{+}$ -ATPase for non-smokers individuals at ages 23-50 years was compared to smokers of the same age group. The enzyme activity of healthy, non-smokers $0.0081 \pm 0.001$ $\mathrm{nmol} \mathrm{Pi} / \mathrm{min} . \mathrm{mg}$ protein was higher compared to smokers $0.0064 \pm 0.001 \mathrm{nmol} \mathrm{Pi} / \mathrm{min}$. mg protein. There was highly significant difference between the two groups $(\mathrm{P}=$ $0.000)$.

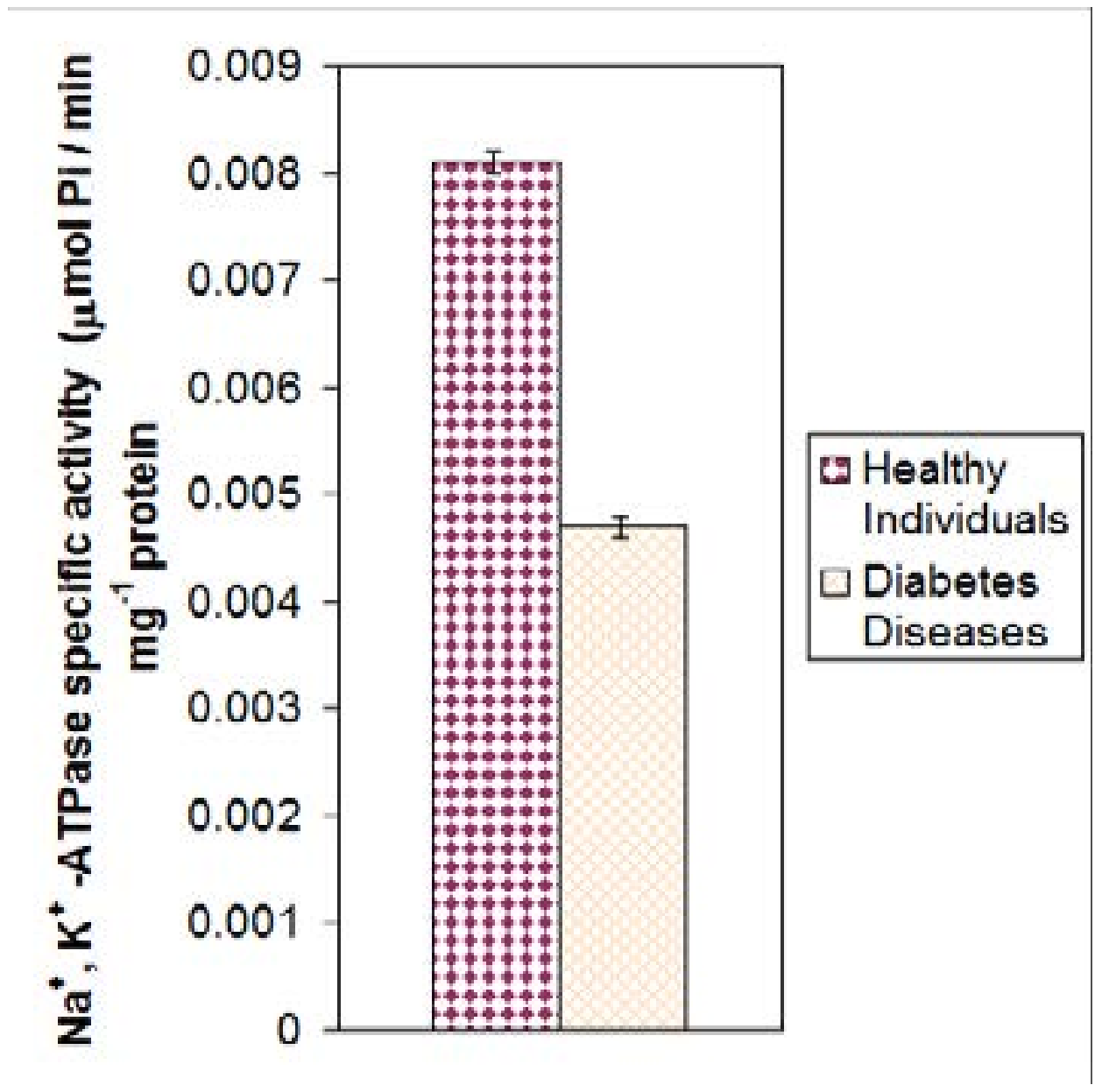

Figure 2: The mean values of $\mathrm{Na}^{+}, \mathrm{K}^{+}$-ATPase specific activity of smokers compared to no smokers $(\mathrm{p}<0.001)$.

In diabetics, as shown in Figure 3 the enzyme activity of the patients was $(n=20)$ compared to healthy individuals (males and females) at 23-50 age group. The mean activity of $\mathrm{Na}^{+}, \mathrm{K}^{+}$-ATPase for healthy group was $0.0081 \pm$ $0.001 \mathrm{nmol} \mathrm{Pi} / \mathrm{min} . \mathrm{mg}$ protein, which was higher than in diabetes patients $(0.0047 \pm 0.002 \mathrm{nmol} \mathrm{Pi} / \mathrm{min}$. mg protein) and the difference was highly significant $\mathrm{P}=0.000$. In kidney disease patients, as shown Figure 4 the enzyme activity of the $\mathrm{n}=15$ was compared with healthy individuals (males and females) at 23-50 age group. The mean activity of $\mathrm{Na}+, \mathrm{K}+$-ATPase for healthy individuals was $0.0081 \pm 0.001 \mathrm{nmol} \mathrm{Pi} / \mathrm{min} . \mathrm{mg}$ protein, which higher compared to kidney diseases patients $0.0069 \pm 0.001$ $\mathrm{nmol} \mathrm{Pi} / \mathrm{min}$. mg protein and the difference was highly significant $(\mathrm{P}=0.000)$.

No significant difference in ATPase activity between males and females. 


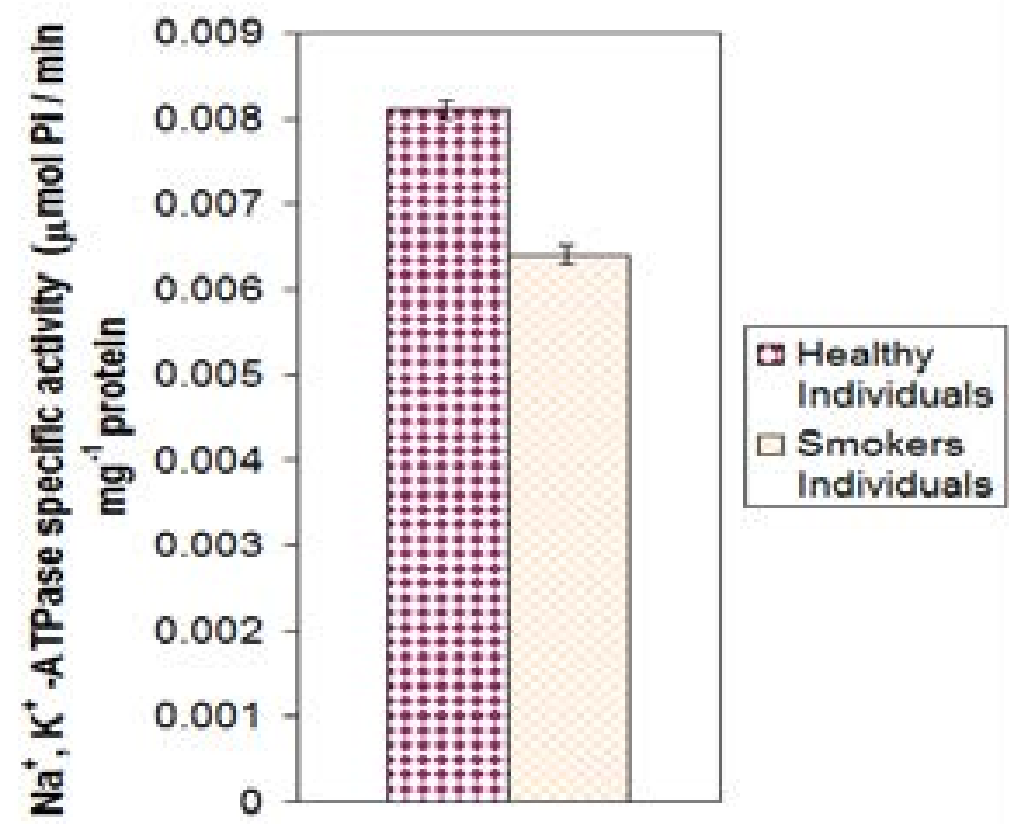

Figure 3: The mean values of $\mathrm{Na}^{+}, \mathrm{K}^{+}$-ATPase specific activity of diabetes patient compared with normal at same age $(\mathrm{p}<0.01)$.

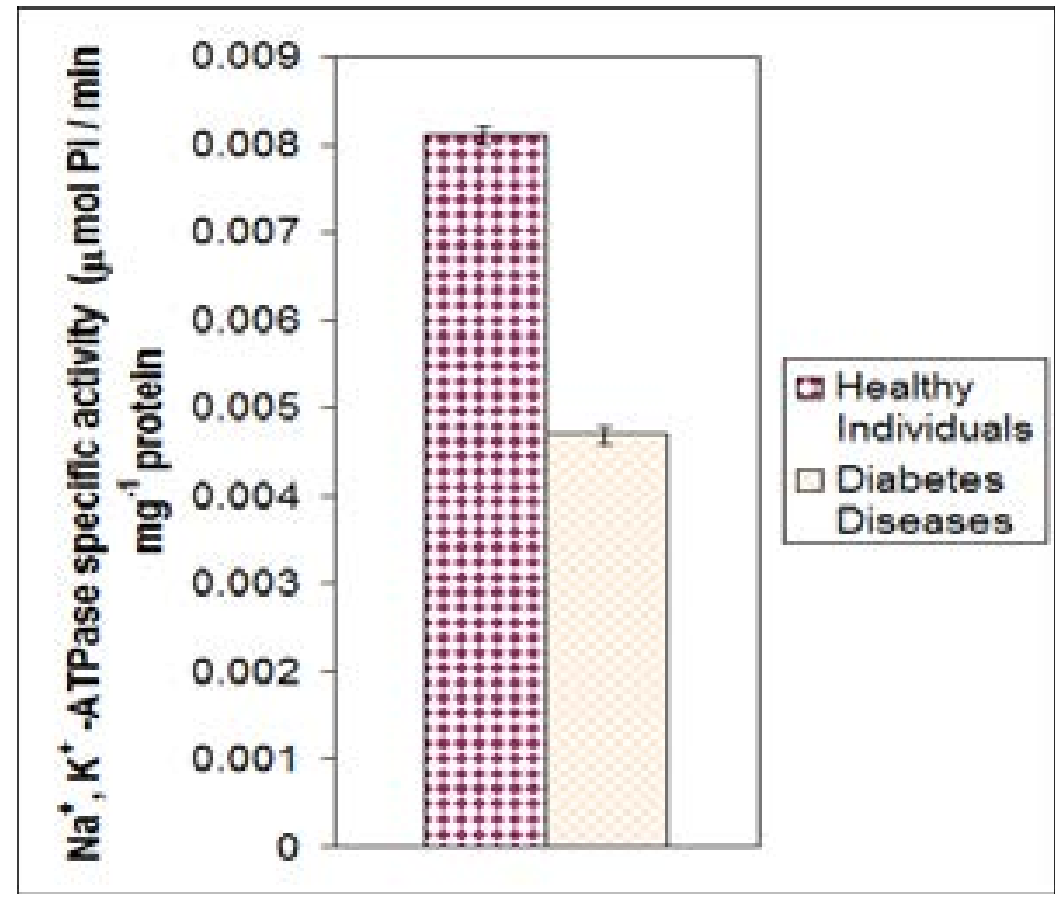

Figure 4: The mean values of $\mathrm{Na}^{+}, \mathrm{K}^{+}$-ATPase specific activity of healthy males and females at age 23-50 years compared to kidney disease $(\mathrm{p}<0.05)$. 


\section{Discussion}

The $\mathrm{Na}^{+} / \mathrm{K}^{+}$-ATPase is a membrane enzyme which is involved in the regulation of membrane potential, cell permeability of $\mathrm{Na}^{+}, \mathrm{K}^{+}$and $\mathrm{Ca}^{2+}$ and excitatory neurotransmitters. It is also important in cell cycle and differentiation. The balance of $\mathrm{Na}^{+}$and $\mathrm{K}^{+}$between the intracellular and extracellular is the main requirement for cellular homeostasis and for different functions ${ }^{3}$. The rationale of this study was the possibility of utilization of $\mathrm{Na}^{+} / \mathrm{K}^{+}$-ATPase as a biomarker for blood diseases.

Previous reports stated that, there is an elevation of $\mathrm{Na}^{+}$, $\mathrm{K}^{+}$-ATPase activity in the primary anemia patients. This elevation may be a compensating mechanism for adaptation of the patients with low oxygen and its physiological role in the cell ${ }^{14}$.

It is assumed that any change in the micro-environmentof blood will have an effect on $\mathrm{Na}^{+}, \mathrm{K}^{+}$-ATPase activity in the red cell membranes. To verify this assumption, the activity of $\mathrm{Na}^{+}, \mathrm{K}^{+}$-ATPase from healthy individuals with different genders but same age group control were compared to those with different physiological conditions. Physiological changes in blood environment are related most of the time with alteration in enzyme specific activity which might be due to increased / decreased concentration of ions, biochemical materials or changes in membrane components and/or structures that is related to that changes.

The result obtained from this study indicated that the mean specific activity of $\mathrm{Na}^{+}, \mathrm{K}^{+}$-ATPase of pregnant women is higher than the healthy women with highly statistically significant difference. This agrees well with published results ${ }^{25}$. This might be due to enzyme relative contribution either to metabolite transport process or/ and to the thermogenesis during pregnancy. However, the increases in both the number and function of the pump may be influenced by factors other than thyroid function ${ }^{26}$. The mean value of specific activity of $\mathrm{Na}^{+}$, $\mathrm{K}^{+}$-ATPase for healthy individuals are higher compared to smokers of the same ages group and gender. This is in agreement with result obtained by Tulenko et $\mathrm{al}^{25}$, where they reported that the $\mathrm{Na}^{+}, \mathrm{K}^{+}$-ATPase activity was decreased in smoker subjects compared with nonsmokers. The suppression in enzyme activity was related to increase in $\mathrm{Na}^{+}$level inside cell. It was suggested that, chronic cigarette smoking causes changes in phospholipid bilayer in cell membrane of blood wall ${ }^{26}$.
The result obtained here indicated that the mean specific activity of $\mathrm{Na}^{+}, \mathrm{K}^{+}$-ATPase of healthy individuals are higher than individuals with diabetes of the same age group and gender, which might be due to the insulin level. If insulin level is low, the rate of glycolysis in red cell become low and leads consequently to decrease the level of ATP so there would be a decreased in the enzyme activity $^{27}$. In vitro insulin treatment of diabetic red cells was found to inhibit the further increase in its activity, but it failed to restore the activity to the normal level ${ }^{26}$.

The mean value of specific activity of $\mathrm{Na}^{+}, \mathrm{K}^{+}$-ATPase for healthy individuals is higher compared to the kidney disease patients at the same age and gender, and the difference is highly significant. This might due to alteration in the ions in blood environment in kidney disease patients, which might lead to a decrease in enzyme specific $\operatorname{activity~}^{28}$.

\section{Acknowledgment}

This project was funded by the Deanship of Scientific Research (DSR), King Abdulaziz University, Jeddah, under grant no. (HiCi-2-141-36). The authors, therefore, acknowledge with thanks DSR for technical and financial support.

\section{Conflict of interest}

The authors declare that, they have no conflict of interest.

\section{References}

1. Bilgin R and Tukel SS 1996. The changes of erythrocyte membrane $\mathrm{Na}^{+}, \mathrm{K}^{+}$-a.ATPase activities in subjects with normal and impaired glucose tolerance. Biochem. Arch., 123: 149-156.

2. Blanco G and Mercer RW. 1998. Isozymes of the $\mathrm{Na}+$ -K+ -ATPase: a. Heterogeneity in structure, diversity in function. Amer. J. Physiol., 275 2: 633-650.

3. Cole CH 1973. Decreased ouabain-sensitive adenosine triphosphatase activity in a. The erythrocyte membrane of patients with chronic renal diseases. Clin. Sci., 45:775.

4. De-La-Tour DD, Raccah D, Jannot MF, Coste T, Rougerie $\mathrm{C}$ and Vague aP. 1998. Erythrocyte $\mathrm{Na}^{+}, \mathrm{K}^{+}$-ATPase activity and diabetes: relationship with $\mathrm{C}$-peptide level. Diabetologia., 419: 1080-4.

5. Djemli-Shipkolye A, Gallice P, Coste T, Jannot MF, Tsimaratos M, a Raccah D and Vague P. 2000. The effects ex-vivo and in vitro of insulin and C-peptide on $\mathrm{Na} / \mathrm{K}$ adenosine triphosphatase activity in red blood cell mem- 
branes of type 1 diabetic patients. Metabolism, 497: 868-72. 6. Djemli-Shipkolye A, Coste T, Raccah D, Vague P, Pieroni G and Gerbi Aa. 2001. Na, K-ATPase alterations in diabetic rats: relationship with lipid metabolism and nerve physiological parameters. Cell. Mol. Biol. Noisy-legrand, 472: 297-304.

7. Finotti P and Palatini P 1986. Reduction of erythrocyte $\mathrm{Na}^{+}, \mathrm{K}^{+}$-ATPase a. activity in type 1 insulin- dependent diabetic subjects and its activation by homologous plasma. Diabetologia., 299: 623-8.

8. Fiske C and Subbarow Y 1925. The colorimetric determination of phosphorus. J a. Biol. Chem., 66: 375-400.

9. Gornall AG, Bardawill GJ and David MM. 1949 Determination of serum a. protein by means of the biuret reaction. J. Biol. Chem., 177:751.

10. Jain SK and Lim G. 2000. Lipoic acid decreases lipid peroxidation and protein a. glycosylation and increases $\mathrm{Na}^{+}, \mathrm{K}^{+}$- and $\mathrm{Ca}^{++}$-ATPase activities in high glucose-treated human erythrocytes. Free Radic. Biol. Med., 2911: 1122-8.

11. Jain SK and Lim G. 2001. Pyridoxine and pyridoxamine inhibits superoxide a. radicals and prevents lipid peroxidation, protein glycosylation, and $\mathrm{Na}^{+}, \mathrm{K}^{+}$- ATPase activity reduction in high glucose-treated human erythrocytes. Free Radic. Biol. Med., 303: 232-7.

12. Jannot MF, Raccah D, Dufayet de la Tour D, Coste T, Gouvernet J and a. Vague P. 1999. Relationship between neuropathy, hypertension and red blood cell $\mathrm{Na} / \mathrm{K}$ ATPase in patients with insulin-dependent diabetes mellitus. Diabetes Metab., 251: 35-42.

13. Kaji DM, Lim J, Shilkoff W and Zaidi W. 1998. Urea Inhibits the $\mathrm{Na}^{+}, \mathrm{K}^{+}$a.pump in human erythrocytes. $J$. Membrane Biol., 165: 125-131.

14. Kimelberg HK \& Papahadjopoulos D. 1972. Phospholipid requirement of $\mathrm{Na}^{+}$, a. $\mathrm{K}^{+}$-ATPase activity: head group specificity and fatty acid fluidity. Biochemica. Biophysica. Acta., 272:282.

15. Kumthekar MM and Katyare SS. 1992. Altered kinetic attributes of $\mathrm{Na}^{+}, \mathrm{K}^{+}$a.-ATPase activity in kidney, brain and erythrocyte membranes in alloxan-diabetic rats. Indian J. Exp. Biol., 301: 26-32.

16. Marija JN. 1985. SPSS/PC+ for the IBM PC/ XT/ AT. SPSS INC. Chicago.USA.

17. Mimura M, Makino H, Kanatsuka A and Yoshida, S. 1992. Reduction of a. erythrocyte $\mathrm{Na}^{+}, \mathrm{K}^{+}$-ATPase activities in non-insulin-dependent diabetic patients with hyperkalemia. Metabolism., 414: 426-30.

18. Parkington HC, Tonta MA, Davies NK, Brennecke SP and Coleman HA. 1999. Hyperpolarization and slowing of the rate of contraction in human uterus in pregnancy by prostaglandins E2 and f2alpha: involvement of the $\mathrm{Na}+$ pump. J. Physiol. 514Pt 1: 229-43.

19. Raccah D, Lamotte-Jannot MF, Issautier T and Vague, P. 1994. Effect of a. experimental diabetes on $\mathrm{Na}^{+}, \mathrm{K}^{+}$ -ATPase activity in red blood cells, peripheral nerve and kidney. Diabete. Metab., 203: 271-4.

20. Ravikumar A, Arun P, Devi KV. and Kurup PA. 2000. Endogenous a. strychnine, nicotine, and morphine-description of hypo and hyper-strychninergic, nicotinergic and morphinergic state in relation to neuropsychiatric diseases. Indian J. Exp. Biol., 386: 559-66.

21. Rohn TT, Hinds TR and Vincenzi FF. 1996. Inhibition of $\mathrm{Ca}^{-}{ }^{2+}$-pump a. ATPase and the $\mathrm{Na}^{+}, \mathrm{K}^{+}$-pump ATPase by iron-generated free radicals: Protection by 6,7-dimethyl-2,4-Di-1-pyrrolidinyl-7H-pyrrolo2,3-dpyrimidine sulfate U-89843D a potent, novel, antioxidant/ free radical scavenger. Biochem. Pharm., 514: 471-476.

22. Serrano R. 1978. Purification and properties of proton-translocating adenosine a. triphosphatase complex of bovine heart mitochondria. Molecular and Cellular Biochemistry. 72:248.

23. Suhail M and Rizvi SI. 1987 Red cell membrane $\mathrm{Na}^{+}$, $\mathrm{K}^{+}$-ATPase in diabetes a.mellitus. Biochem. Biophys. Res. Commun., 1461: 179-86.

24. Tosukhowong P, Tungsanga K, Eiam-Ong S. and Sitprija V. 1999a. Environmental distal renal tubular acidosis in Thailand: an enigma. Am. J. Kidney Dis., 336: 1180-6.

25. Tulenko TN, Rabinowitz JL, Cox RH. and Santamore WP. 1988. Altered a. $\mathrm{Na}^{+}, \mathrm{K}^{+}$-ATPase, cell $\mathrm{Na}+$ and lipid profiles in canine arterial wall with chronic cigarette smoking. Int. J. Biochem., 203: 285-9.

26. Vasilets CA. and Schwarz W. 1993. Structure-function relationships of cation a.binding in the $\mathrm{Na}^{+}, \mathrm{K}^{+}-\mathrm{ATP}$ ase. Biochim. Biophys. Acta., 1154: 201-222.

27. Yoshimura M, Nishikawa M, Ogasawara H, Horimoto M, Yoshikawa N.a Sawaragi I. and Inada M. 1993 Measurement of erythrocyte $\mathrm{Na}^{+}, \mathrm{K}^{+}$-ATPase activity in normal pregnant women. Endrocr J., 401: 171-7.

28. Zamora F and Arola L. 1987. $\mathrm{Na}^{+}, \mathrm{K}^{+}$-ATPase activities in rat tissues during a. pregnancy. Biol. Res. Pregnancy Perinatol., 822D Half: 89-92. 